\title{
Study on Effects of Regulation by Switching Costs in Mobile Communication Consumption of College Students
}

\author{
Ninghui Xie' ${ }^{1}$ Chunyu Zhao², Defeng Yang1 \\ ${ }^{1}$ Management School, Jinan University, Guangzhou, China \\ ${ }^{2}$ School of Business, Sichuan Normal University, Chengdu, China \\ Email: sherryxienh@gmail.com
}

Received 5 October 2014; revised 2 November 2014; accepted 24 November 2014

Copyright (C) 2014 by authors and Scientific Research Publishing Inc.

This work is licensed under the Creative Commons Attribution International License (CC BY). http://creativecommons.org/licenses/by/4.0/

cC) (7) Open Access

\begin{abstract}
A theoretical hypothesis that switching costs have effects of regulation is proposed by analyzing relations among switching costs, customer satisfaction and customer loyalty in the field of mobile communication consumption of enrolled college students. Then relevant data are acquired from questionnaires, processed with SPSS 20.0 Statistical Program and subjected to hierarchical regression analysis to test the hypothesis. Finally, it is concluded that, among different dimensions of switching costs, procedural switching costs have a significant effect of regulation between customer satisfaction and customer loyalty, but the financial and relational switching costs have not significant moderating effect. Thus, to improve customer loyalty, operators are suggested to enhance customer satisfaction and procedural switching costs simultaneously.
\end{abstract}

\section{Keywords}

Mobile Communication, Switching Costs, Regulation Effect, Customer Satisfaction, Customer Loyalty

\section{Introduction}

Competition on China's mobile communication market grows increasingly fierce nowadays. Universities and colleges form a giant market, which becomes a hot battlefield for the three major communication network operators. Operators keep releasing various sales promotions to improve customer satisfaction, seize more market shares and attract more new customers. Services and prices provided by operators who don't have the biggest market share seem attractive. However, switch by a large quantity of student customers among operators has not 
happened yet.

Previous theoretical studies have shown that, switching cost is an important factor. Customer satisfaction does have a significant positive influence over customer loyalty but is not enough to maintain customer loyalty, and that customer loyalty is also affected by switching costs of customers [1]. For different dimensions of switching costs, relation between customer satisfaction and customer loyalty may differ. And the behavior of student customers may be also different from other categories of customers.

This paper is based on an empirical study on relations among switching costs, customer satisfaction and customer loyalty in the field of mobile communication consumption of college students, to further explore the mechanism of action thereof.

\section{Literature Review and Study Hypotheses}

\subsection{Customer Satisfaction and Customer Loyalty}

According to the expected-perceived model, customer satisfaction is a measure of how a customer feels about comparison between perceived condition and expected condition of a service. Attitudinal customer loyalty is an attitude of a customer preferring or relying on a product or service, with high level of attitudinal loyalty, customers have high level of psychological attachments and attitudinal advocacy; which may lead to positive word of mouth, while behavioral customer loyalty is a behavior of the customer with such an attitude buying the product or service [2]. Defined by Dick (1994), loyalty is a combination of both attitudinal loyalty and behavioral loyalty, it implies "the strength of the relationship between an individual's relative attitude and their repeat patronage" [3]. This means, a customer who is satisfied by the previous service feels good, prefers the service emotionally, and tends to adopt a behavior of secondary consumption to feel satisfied again. Many scholars in China and abroad point out that, customer satisfaction has positive influence over and is an important drive to customer loyalty [2]-[5]. Therefore, a hypothesis comes as below from the aforesaid analysis:

H1: Customer satisfaction has a positive influence over customer loyalty.

\subsection{Customer Satisfaction, Customer Loyalty and Switching Costs of Customers}

Practices tell us that, a part of customers with relatively high satisfaction do not always keep their loyalty to products or services used currently when other suppliers' products or services are available. Loyalty does not depend on customer satisfaction only. In other words, a satisfied customer may be not loyal. Fornell (1992) thinks that, an enterprise locks in its customers by means of not only customer satisfaction, but also switching costs of customers, which occurs when a customer switches between different product/service suppliers [6]. According to Bumham et al. (2003), switching cost is the onetime costs that "customers associate with the process of switching from one provider to another" [7]. Switching costs include labor costs and economic costs used by customers to search, losses of money, materials and personal relationship that might arise from abandoning current suppliers, and psychological risks, consumption habits and emotional costs that customers perceive when they are switching. A representative classification of switching costs made by Burnham et al. (2003) is comprised of three dimensions, i.e., procedural switching costs, financial switching costs and relational switching costs [7]. Procedural switching costs include economic risk costs, evaluation costs, learning costs and setup costs. Financial switching costs include benefit loss costs and monetary loss costs. Relational switching costs include personal relationship loss costs and brand relationship loss costs.

Due to the asymmetric policy of switching from one operator to another without changing telephone number, most of mobile users who want to switch must change their mobile phone numbers. Such a user has to spend certain time and energy notifying his or her contacts of new number, to avoid impacts on personal relationship. As a result, setup costs increase. Furthermore, some users, who have their mobile phone numbers registered for some websites, micro-blogging, QQ, e-mails or games, may suffer from certain economic risk costs and evaluation costs. Hence, certain procedural switching costs exist in switching among operators.

Since competition among network operators in universities and colleges is quite fierce and preferential promotions are launched one after another, a college student only has to pay a relatively low financial cost to enjoy benefits from these sales promotions. For users who are students, financial switching costs are low.

By subscribing for a campus network, mobile users of one operator can enjoy preferential prices for calling each other and consolidate their personal relationships in the network. Switching to another operator may well 
impair existing personal relationships and loss thereof may incur relational switching costs. Furthermore, for consumers who built up their identifications by associating themselves with the brand or company through purchases [8], when they switch, their identifications may suffer, thus may also result in affective losses.

According to previous studies on effects of switching costs, most scholars thought that, switching costs impact customer loyalty directly. For example, by analyzing mobile communication data of Taiwan, Hu and Hwang (2006) find that, customer loyalty is significantly affected by procedural switching costs and relational switching costs, and insignificantly affected by financial switching costs [9]. And Ting investigates the conditioning effect of customer satisfaction between switching cost and consumers' repurchase intention, the results show that the effect is significant [10]. Ting's research reveals variables that will affect behavioral loyalty instead of combined loyalty.

But if we define customer loyalty as a combination of attitudinal loyalty and behavioral loyalty, we believe switching costs have effects of regulation between customer satisfaction and customer loyalty. On the premise that customers are satisfied, customers seeing low switching costs tends to behave disloyally to original products or services, while customers seeing high switching costs will not change products or services easily and will keep a relatively high loyalty even if market competition is fierce. That is to say, switching costs have effects of regulation between customer satisfaction and customer loyalty.

Following hypotheses are proposed in this paper based on the aforesaid analysis, and a theoretical hypothesis model is established as shown in Figure 1 for this study.

H2a: Procedural switching costs have significant effects of regulation between customer satisfaction and customer loyalty;

H2b: Financial switching costs have significant effects of regulation between customer satisfaction and customer loyalty;

H2c: Relational switching costs have significant effects of regulation between customer satisfaction and customer loyalty.

\section{Study Design}

\subsection{Data Acquisition}

Survey objects for this study are students using mobile communication services, who are enrolled in universities and colleges all over China (mainland). In this survey carried out on-line, totally 300 questionnaires were issued to 300 students in Beijing, Hunan, Inner Mongolia, Heilongjiang, Sichuan, Shanghai and Guangdong, etc. Actually 277 questionnaires were recovered, with the recovery rate being $92.3 \%$ or so. From the perspectives of gender, grade, region and operator, distributions of samples were relatively rational and representative.

\subsection{Measures}

Scales for customer satisfaction and customer loyalty are relatively mature. In this study, we adapted scales from previous study [11] and modified the scale to suit the situation of telecommunication field. Scales were all expressed from the first person point of view, to avoid influence of objective situational factors. Studies of Hu and Hwang (2006) were referred for scale for switching costs, the scale consisted of three dimensions: procedural switching cost, financial switching cost and relational switching cost [9]. The scale was revised to needs of this study and based on characteristics of perception of switching costs of college students. To improve validity of

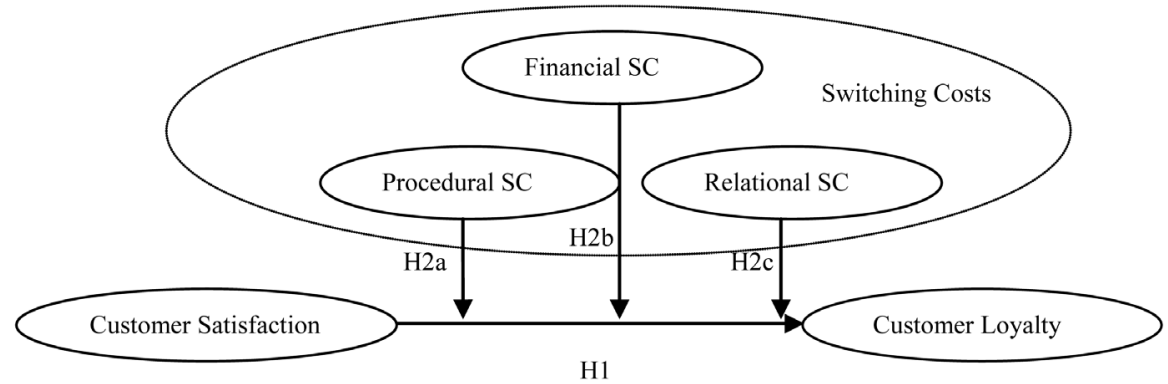

Figure 1. Research structure. 
scales, we translated original scales, carried out discussion and pretest and worked out final scales through revision for survey use. Questionnaire survey employed 7-point Likert scales, with figures from 1 through 7 representing levels of agreement about each statement. "1" is for "totally disagreed", while "7" for "totally agreed".

\subsection{Study Methods}

To study the effects of regulation for this paper, data about customer satisfaction, customer loyalty and switching costs in the field of mobile communication consumption of enrolled college students were acquired through questionnaires and listed in a 7-point Likert scale, and a hierarchical regression model was employed. The following test steps were followed: 1) Do regression analysis between value of dependent variable and values of independent and moderator variables; 2) After centering of the independent and moderator variables, do regression analysis among the valve of the dependent variable, the values of the independent and moderator variables and interaction term (product term) of the latter two variables; 3 ) Compare values of coefficient $\mathrm{R}^{2}$ measured at the two hierarchies, and effects of regulation are significant if the latter $\mathrm{R}^{2}$ is significantly higher than the former one [12]. What's more, since switching costs are composed of three dimensions, i.e., procedural switching costs, financial switching costs and relational switching costs, the three dimensions are subjected to hierarchical regression analysis respectively in this paper for the purpose of convenient computation.

\section{Data Analysis}

\subsection{Reliability Analysis}

For this research, a coefficient of internal consistency, Cronbach's $\alpha$, was applied to reliability analysis of samples. As shown in Table 1, all the terms passed reliability test, each $\alpha$ value was higher than 0.7 , and total reliability of questionnaires was 0.902 . The reliability result was relatively good and met study requirement.

\subsection{Analysis of Influence of Customer Satisfaction over Customer Loyalty}

Regression analysis was conducted on the influence of customer satisfaction over customer loyalty, with Spss 20.0 Statistical Program. Analysis result was as shown in Table 2. The correlation coefficient of customer satisfaction and customer loyalty was 0.711 , and determination coefficient $R^{2}$ was 0.506 , which was 0.503 after adjustment. Because there was only one regression model, variation of $R^{2}$ was 0.506 , equal to statistic of $R^{2}$. This meant: the variable of customer satisfaction could explain $50.6 \%$ of variance of customer loyalty; $\mathrm{F}$ value was 170.841 and the corresponding $p$ value was less than the significance level of 0.001 ; explained variance of the regression model reached the significance level. As a result, H1 was supported. Customer satisfaction has a positive influence on customer loyalty.

Table 1. Reliability coefficients of variables.

\begin{tabular}{cc}
\hline Variables & Cronbach's $\alpha$ \\
\hline Customer Satisfaction & 0.863 \\
Customer Loyalty & 0.887 \\
Procedural Switching Costs & 0.732 \\
Financial Switching Costs & 0.767 \\
Relational Switching Costs & 0.787 \\
\hline
\end{tabular}

Table 2. Regression analysis of customer satisfaction and customer loyalty.

\begin{tabular}{ccccc}
\hline $\mathrm{R}$ & $\mathrm{R}^{2}$ & Adjusted $\mathrm{R}^{2}$ & $\mathrm{~F}$ & Sig. \\
\hline 0.711 & 0.506 & 0.503 & 170.841 & 0.000 \\
\hline
\end{tabular}


Table 3. Analysis of moderating effects.

\begin{tabular}{cccccc}
\hline Moderator & Steps & Regression Equation & $\mathrm{R}^{2}$ & $\Delta \mathrm{R}^{2}$ & $\mathrm{t}$ \\
\hline $\begin{array}{c}\text { Procedural } \\
\text { switching costs }\end{array}$ & 1 & $\mathrm{Y}=0.083 \mathrm{P}+0.685 \mathrm{X}$ & 0.512 & - & - \\
Financial & 1 & $\mathrm{Y}=-0.062+0.128 \mathrm{P}+0.653 \mathrm{X}+0.172 \mathrm{PX}$ & 0.548 & $0.036^{* *}$ & 3.643 \\
switching costs & 2 & $\mathrm{Y}=-0.011+0.078 \mathrm{~F}+0.666 \mathrm{X}+0.032 \mathrm{FX}$ & 0.514 & 0.002 & 0.824 \\
$\begin{array}{c}\text { Relational } \\
\text { switching costs }\end{array}$ & 1 & $\mathrm{Y}=0.148 \mathrm{R}+0.602 \mathrm{X}$ & 0.516 & - & - \\
\hline
\end{tabular}

Note: ${ }^{* *} p<0.01$; Y: Customer loyalty; X: Customer satisfaction; P: Procedural switching costs; F: Financial switching costs; R: Relational switching costs.

\subsection{Analysis of Effects of Regulation}

Computation was conducted for the three dimensions of switching costs respectively in this Study for the purpose of convenient computation, according to study methods applied by Wen et al. (2005) to effects of regulation [12] (See Table 3 for results of data processing).

For procedural switching costs, regression of product term (PX) in Step 2 was significant, where $t=3.643$ and variance of $\mathrm{R}^{2}$ was about $3.6 \%$, so procedural switching costs had a significant effect of regulation [13]. Regression coefficient for relation between customer loyalty and customer satisfaction was $0.172 p+0.653$, which was a linear function of $p$. That meant, the higher the procedural switching costs, the greater the positive influence of customer satisfaction over customer loyalty. Hence, H2a was proved. As for regression analysis of financial switching costs, $t=0.824$ and variance of $\mathrm{R}^{2}$ was about $0.2 \%$, where the effect of regulation was insignificant. Hence H2b was not proven. When it came to relational switching costs, $t=1.405$ and variance of $\mathrm{R}^{2}$ was about $0.5 \%$, where the effect of regulation was insignificant. H2c was not supported.

\section{Conclusions and Suggestions}

In this paper, the effects of regulation by three dimensions of switching costs between customer satisfaction and customer loyalty is studied based on mobile communication consumption of college students. It is concluded that customer satisfaction has a positive significant influence over customer loyalty, which is in line with results of previous studies. Among the dimensions of switching costs, procedural switching costs have a significant positive effect of regulation. In other words, the higher the procedural switching costs, the more loyal the satisfied customers are. However, the effects of regulation by financial switching costs and relational switching costs are insignificant. For financial switching costs, we suppose this is because, compared with procedural switching costs, financial cost is not very important, for many customers, the accumulated credits are useless and the financial cost of telecom card is one-off. As for relational switching costs, we believe this is because the brands of operators are not yet powerful enough and customers seldom build personnel relations with service persons of operators. And this is the situation telecom operators want to change.

Consequently, to enhance customer loyalty, operators must increase procedural switching costs of customers in addition to improving customer satisfaction. Operators are suggested to improve their service quality, expand coverage of their networks and improve communication quality during growth of customers to keep a high customer satisfaction for mobile communication services. Operators are also suggested, at the same time, to develop relevant products, provide more service packages of higher value that are closely related to customers' daily life, and increase procedural switching costs of customers. Particularly, nowadays college students use a lot of web interaction products, registration at most of which is for free. So operators can develop products in relevant fields and promote bundled use, to raise value perceived by customers, to satisfy customers and increase their switching costs and hence to keep high customer loyalty.

\section{References}

[1] Lam, S.Y., Shankar, V., Erramilli, M.K. and Murthy, B. (2004) Customer Value, Satisfaction, Loyalty, and Switching Costs: An Illustration from a Business-to-Business Service Context. Journal of the Academy of Marketing Science, 32, 
293-311. http://dx.doi.org/10.1177/0092070304263330

[2] Jahanzeb, S., Fatima, T. and Khan, M.B. (2011) An Empirical Analysis of Customer Loyalty in Pakistan's Telecommunication Industry. Journal of Database Marketing and Customer Strategy Management, 18, 5-15. http://dx.doi.org/10.1057/dbm.2011.2

[3] Dick, A.S. (1994) Customer Loyalty: Toward an Integrated Conceptual Framework. Journal of the Academy of Marketing Science, 22, 99-113. http://dx.doi.org/10.1177/0092070394222001

[4] Li, X.G. and Duan, X.K. (2011) The Relationship among Switching Cost, Customer Satisfaction and Customer Loyalty Based on Mobile Communication Customer Behavior. China Soft Science, 4, 154-160. http://dx.doi.org/10.3969/j.issn.1002-9753.2011.04.018

[5] Zhang, X.A. and Tian, P. (2007) An Empirical Study of Relation Between Customer Satisfaction and Customer Loyalty. Journal of Management Sciences in China, 4, 62-72.

[6] Fornell, C. (1992) A National Customer Satisfaction Barometer: The Swedish Experience. Journal of Marketing, 56, 6-21. http://dx.doi.org/10.2307/1252129

[7] Burnham, T.A., Frels, J.K. and Mahajan, V. (2003) Consumer Switching Costs: A Typology, Antecedents, and Consequences. Journal of the Academy of Marketing Science, 31, 109-126. http://dx.doi.org/10.1177/0092070302250897

[8] Wu, E., Cutright, K. and Fitzsimons, G. (2011) How Asking “Who Am I?” Affects What Consumers Buy: The Influence of Self-Discovery on Consumption. Journal of Marketing Research, 48, 296-307. http://dx.doi.org/10.1509/jmkr.48.2.296

[9] Hu, A.W. and Hwang, I.S. (2006) Measuring the Effects of Consumer Switching Costs on Switching Intention in Taiwan Mobile Telecommunication Services. Journal of American Academy of Business, 9, 75-85.

[10] Ting S.C. (2014) The Relationship Between Customers' Switching Cost and Repurchase Intention: The Moderating Role of Satisfaction. Journal of Service Science and Management, 7, 313-322. http://dx.doi.org/10.4236/jssm.2014.74028

[11] Lam, S.Y., Shankar, V., Erramilli, M.K. and Murthy, B. (2004) Customer Value, Satisfaction, Loyalty, and Switching Costs: An Illustration from a Business-to-Business Service Context. Journal of the Academy of Marketing Science, 32, 293-311. http://dx.doi.org/10.1177/0092070304263330

[12] Wen, Z., Hau, K.T. and Chang, L. (2005) A Comparison of Moderator and Mediator and Their Applications. Acta Psychologica Sinica, 37, 268-274.

[13] Cohen, J. and Cohen, P. (1975) Applied Multiple Regression/Correlation Analysis for the Behavioral Sciences. Erlbaum Associates, Hillsdale, New Jersey. 
Scientific Research Publishing (SCIRP) is one of the largest Open Access journal publishers. It is currently publishing more than 200 open access, online, peer-reviewed journals covering a wide range of academic disciplines. SCIRP serves the worldwide academic communities and contributes to the progress and application of science with its publication.

Other selected journals from SCIRP are listed as below. Submit your manuscript to us via either submit@scirp.org or Online Submission Portal.
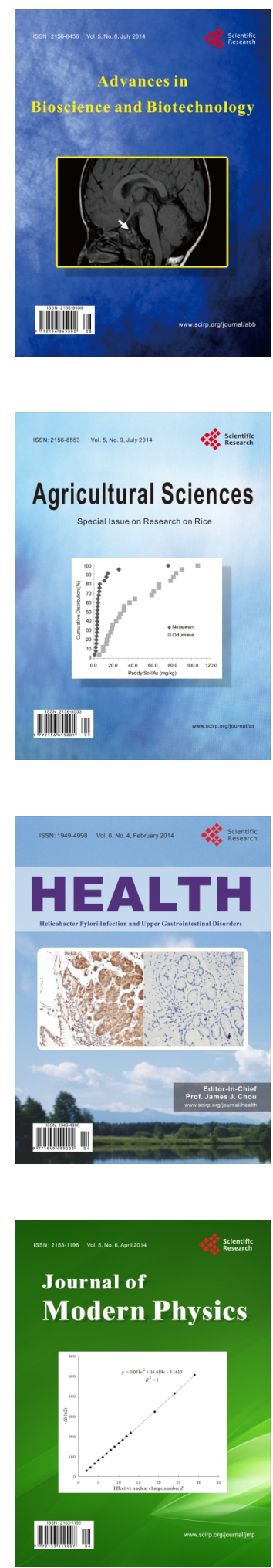
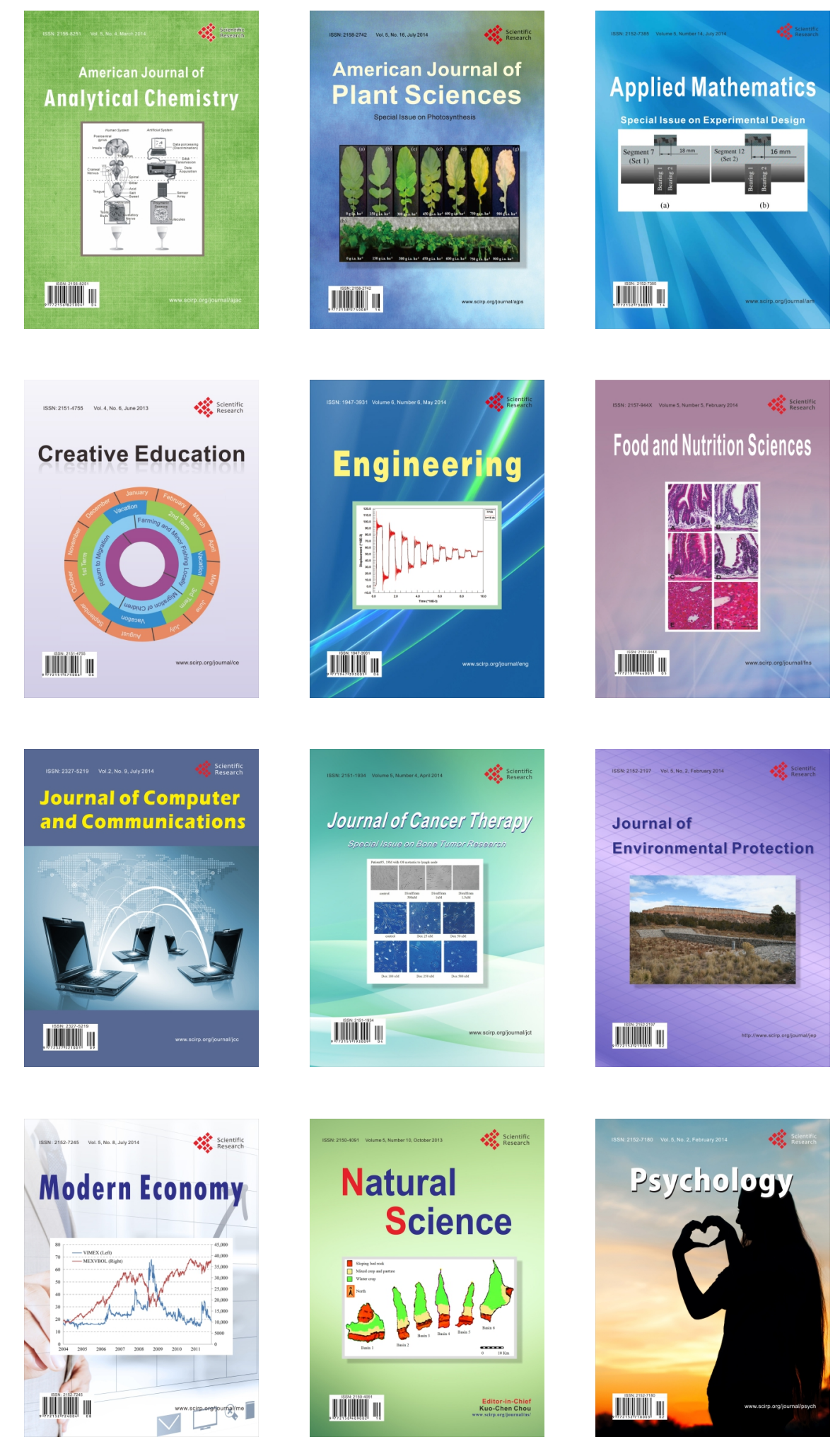